\title{
THE MEANING OF THE RIGHT TO SOCIAL SECURITY
}

\author{
JEF VAN LANGENDONCK*
}

\begin{abstract}
RESUMO: Este artigo trata inicialmente do desenvolvimento histórico do conceito de seguridade social. Começa com as características e o espírito por trás da inclusão deste direito na Declaração Universal dos Direitos Humanos. Ele então discute o já ancião paradigma estabelecido pela OIT e o approach neo-liberal do Banco Mundial, apontando os méritos tanto quanto desmascarando as falhas de ambas teorias. Conclui então oferecendo um novo conceito de seguridade social internacional através da colaboração entre nações, baseada principalmente no princípio da solidariedade. PALAVRAS-CHAVE: Seguridade Social, Direitos Humanos, Solidariedade.
\end{abstract}

ABSTRACT: This article initially dwells on the concept of social security's historical development. It starts with the characteristics and the spirit behind the inclusion of such right in the Universal Declaration of Human Rights. It then discusses the now ancient paradigm set by the I.L.O and the neo-liberal approach by the World Bank, pointing both theories merits as well as unmasking their flaws. It concludes by offering a new concept of international social security via the collaboration between nations, grounded mainly on the solidarity principle.

KEYWORDS: Social Security, Human Rights, Solidarity.

SUMMARY: 1. Birth of a Right; 2. But what does it mean?; 3. I.L.O. Convention No. 102; 4. A new conception: the social security program of the World Bank; 5 . Time for an international scheme?

\section{BIRTH OF A RIGHT}

On the $16^{\text {th }}$ of February 1946, practically to the day 60 years ago, the United Nations appointed a Commission on Human rights, under the chairmanship of Mrs. Roosevelt, widow of the U.S. president. After two years of discussions, the Committee presented to the General Assembly a draft of a Universal Declaration of Human Rights, which was adopted by the General Assembly on 10 December 1948, by 48 votes to 8 abstentions. ${ }^{1}$ Article 22 of this Declaration proclaimed that "Everyone, as a member of society, has the right to social security". It was the birth of a new right: the right to social security.

The primary aim of the Committee was to prepare an international instrument banning "forever" the violations of human rights as committed by the Nazi regime of

\footnotetext{
* President of the Belgian Association of Social Security. Professor of the Institute of Social Law, Catholic University of Louvain, Belgium.

${ }^{1}$ The Soviet countries did not vote against the declaration, but abstained, because they considered that the text did not go far enough.
} 
Germany in the years before. The inclusion of the "social and economic rights" in articles 22 to 26 of the Declaration also referred to the wartime experience. The Nazis made it an instrument of their propaganda, pointing out how well workers were protected in Germany, in contrast with the conditions in Britain and the US during the depression years before the war. The governments of the allied powers went out of their way to counteract this all too true observation, to which the working classes in their countries showed themselves to be very sensitive. On the $14^{\text {th }}$ of August 1941 Churchill and Roosevelt agreed the "Atlantic Charter", in which they stated the aims of the warfare. As the fifth item in this charter they put: the desire "to bring about the fullest collaboration between all nations in the economic field with the object of securing, for all, improved labor standards, economic advancement and social security”.

There may have been, however, a secret agenda that had more to do with economy and trade. Already from the times of president Woodrow Wilson, the U.S. were the apostles of free trade. In the "Atlantic Charter" the concern about international trade preceded that about labour standards and social security. Point four of the charter said that "they will endeavour, with due respect for their existing obligations, to further the enjoyment by all States, great or small, victor or vanquished, of access, on equal terms, to the trade and to the raw materials of the world which are needed for their economic prosperity". In the American view, social security was always linked with this concern. Enterprises would be willing to pay social security tax, only if their competitors were forced to bear the same burden. One should not forget that the Social Security Act itself was based upon the federal competence on interstate commerce, social policy being a competence of the States, not of the Federal Government. Clearly, in the post-war world of free trade, the U.S. wanted not only to make sure that the populations of all nations in the world would enjoy social security, but also to impose the financial burden of social security on enterprises in all these nations, tghat would be their business partners.

This idea of social security as a universal right was very new at the time. One has to remind oneself of the fact that until ten years previously, nobody had ever heard of anything called "social security". ${ }^{2}$ The term was used in the "Social Security Act” of 1935 by president Roosevelt, and it comes as no surprise that his widow used the same term in the Declaration drafted by her Committee. It also comes as no surprise that New Zealand and Australia were among the countries that acclaimed most vigorously, during the debate in the General Assembly, the inclusion of these social rights and of the right to social security in particular. New Zealand had followed the American example and adopted already in 1938 an act on "social security". And Australia had instituted in 1947 a universal, even if means tested, social security program.

What is more surprising, is that other countries, with much older social protection systems, usually called "social insurance", adopted this new terminology without hesitation, not only for international instruments, but often also in their national

\footnotetext{
${ }^{2}$ Except the inhabitants of Bolivia, since it appears that Simon Bolivar used the term "Seguridad social” as early as 1819 .
} 
legislation. In the tradition of these countries, originating in the "social problem" of the $19^{\text {th }}$ century, social insurance was meant for workers, employed in private enterprises. It was always associated with labour law and labour protection. To consider it as a fundamental human right, to be enjoyed equally by all citizens, was for these countries a novel idea. It has been observed, in fact, that some of these countries (such as France and Belgium) have at first, immediately after the war, adopted legislation proclaiming the right of social security for everyone, but immediately afterwards watered these systems down to schemes for employed workers, to be extended later - mostly much later - to other groups of the population.

The soviet countries, who abstained from the vote, were in fact much closer to the principle of the "right to social security", since they assured the right to work and the right to social protection to all workers, and they considered all citizens as workers. In later years they have frequently used their social protection policy as a strong weapon in the propaganda, that was part of the so-called "cold war", much in the same way as Nazi-Germany did in the preceding period.

Absent in the debate were the less developed countries, who were members of the UN (which the case only of a limited number of them, since many still had the status of colony or dominion). The representatives of Cuba, the Philippines, India, Pakistan, China [Taiwan], Bolivia, Egypt etc. spoke in the General Assembly about political and religious matters, but said nothing about art 23 or the social and economic rights. They probably did not feel concerned by them, considering that to guarantee such rights for their populations was impossible, anyhow.

\section{BUT WHAT DOES IT MEAN?}

It will be noted that art. 25 gives some sort of definition of social security, by listing in a broad way the "social risks" to be covered: "Everyone has the right to a standard of living adequate for the health and well-being of himself and of his family, including food, clothing, housing and medical care and necessary social services, and the right to security in the event of unemployment, sickness, disability, widowhood, old age or other lack of livelihood in circumstances beyond his control." In doing so it runs the risk of limiting a right which article 22 wanted to state as broadly as possible. One notices, for instance, that "widowhood" seems to apply only to women. But it is careful to add an open item: all other lack of livelihood in circumstances beyond his control, so that it cannot be interpreted in a limitative sense. So the concept of "social security" was left open to later definition.

In the General Assembly it was stressed by a number of interventions in the debate, notably from the soviet countries, that the declaration should be followed by a convention, establishing clear legal rules and procedures, in order to ensure that member countries would observe their obligations. This was finally done by the "International Covenant on Economic, Social and Cultural Rights” of 16 December 1966, but without real enforcement mechanism, and without any clearer definition of the "right to social security".

Art. 9 of the Covenant repeats the wording of the Declaration concerning "the right of everyone to social security", but it adds: "including social insurance". This text makes it clear that assistance-type basic and means-tested benefits can be 
part of the social security which states provide for their citizens, but that it cannot be sufficient. The right to social security includes the right to social insurance, this means to insurance-type benefits to which the beneficiary has a subjective entitlement on the basis of his contributions. Such a right is similar to a property right and cannot be subject to discretionary administration.

It should be noted that the article speaks of the right of "everyone" to such social security. It therefore cannot be sufficient to provide social insurance to most of the population, completing this with social assistance for the persons not covered by this scheme: the right to social insurance is meant to be a right for everyone, and its benefits can be completed and topped up by assistance and by other types of benefits.

The Covenant is less informative on other aspects. It doesn't repeat the specification of the social security right according to covered risks, as in article 25 of the Declaration, which must have seemed a risky business. It may also have appeared as superfluous after the I.L.O. Convention No. 102, which we will discuss next. Many states also will have not been ready to commit themselves to offer protection for their people in all these precise circumstances, prefering a general pledge to create a system which they call "social security".

The Covenant is much more precise in the matter of health. This is clear from section 2 of article 12, which enumerates a whole (not exhaustive) list of measures to be taken by member countries in the matter of health protection. The fact that most countries, as members of the World Health Organization, were already committed to the principles of that organization will have helped the international community to overcome its shyness of precise obligations for member states in this respect.

Even if the Covenant is a legally binding text, the obligations for the states under it is in reality a moral one. The states have to report to the U.N. about their compliance with the Covenant, but no Court is set up to condemn them if they don't and no real sanctions can be taken against them. In reality the Covenant doesn't play a very important role. It is more often forgotten than applied.

\section{I.L.O. CONVENTION NO. 102}

One reason why the Declaration and the International Covenant remained vague about the meaning of the "right to social security" was, that a specialised institution under the U.N., the International Labour Organisation (I.L.O.) had the explicit mission of establishing international labour standards, including social security. It was certainly felt that it was better - and also more comfortable - to leave this matter to the specialists. The I.L.O. reponded to this expectation by issuing Convention No. 102 concerning Minimum Standards of Social Security of the International Labour Organization, concluded in Geneva on 28 June 1952.

This Convention was in essence a compromise between the old "Bismarckian” social insurance for workers, and the new "Beveridgian" social security for all. The I.L.O. could not turn away from its earlier conventions on individual branches of social insurance. ${ }^{3}$

\footnotetext{
${ }^{3}$ See: Convention no. 24 on health insurance (1927), Conventions No. 35 to 40 on old age, invalidity and death (1933) and Convention no. 44 on unemployment (1934).
} 
It incorporated them into a larger instrument, extending to all branches, and providing for a larger coverage, not only of industrial workers but of other citizens as well. It did this by allowing member countries to choose, when ratifying the convention, between covering a certain percentage (typically 50\%) of industrial workers or a lower percentage of the active population (20\%), or a certain percentage of all residents. ${ }^{4}$ In this way, the Convention falls clearly short of the principle of the Declaration, which is to make the right to social security a fundamental right of everyone as a member of society. It would seem that the I.L.O. allows its member countries to consider large groups of workers or of residents as not being part of human society.

Also in the matter of the object of this right, the I.L.O. Convention is unsatisfactory. Parts II to X of the convention list the following nine branches of benefit: medical care, sickness benefit, unemployment benefit, old-age benefit, employment injury benefit, family benefit, maternity benefit, invalidity benefit, and survivors' benefit. But in ratifying the convention, member states can choose to provide for only three of these branches, of which one must be from the group: unemployment, old-age, employment injury, invalidity or survivors benefit. This means that the protection offered, even by a member country having ratified the convention, could fall far short of what article 25 of the Declaration promises.

Half a century later, the Convention appears to be out-dated. Its list of "contingencies" is derived directly from the old German-British-French social insurance schemes between the two world wars. This is not suitable anymore for modern social protection.

One finds in this list instances of loss of earnings from work, such as sickness, invalidity, unemployment, but also instances of heavy and socially significant costs, such as medical care and family charges.

The first group contains typical causes of loss of earnings. But modern social protection policy would not concentrate on the cause of the loss, but on its nature and duration: short-term or long-term, temporary or permanent. And in the second group it omits other types of costs that are equally heavy and socially significant, such as housing, education and training, and social integration for handicapped persons.

It is also open to accusations of discrimination. It lays, for instance, a lot of emphasis on employment accidents and occupational diseases, providing typically for a higher benefit in the case of employment related disease or injury as compared to disease or injury not caused by employment. ${ }^{5}$ This would in a modern view be considered as discriminatory. It also speaks in article 60 and 61 of "widows" and "wives" when it comes to survivors' benefits, what should not be acceptable anymore.

We don't want to create a misunderstanding: it is certainly a fact that the I.L.O. adapts its instruments to new situations and conceptions and that most of its social security conventions have already been revised. ${ }^{6}$ Michael Cichon will speak to us

\footnotetext{
${ }^{4}$ Only $50 \%$ of all residents for health care, and $20 \%$ for family benefits.

${ }^{5}$ Schedule to Part XI of the Convention.

${ }^{6}$ A. Otting, "The International Labour Organization and its Standard-Setting Activity in the Area of Social Security”, in: Journal of European Social Policy, 1994, 4, 51). But certain basic conceptions as in Convention No. 102 have not been adapted.
} 
about the modern-day policies of the I.L.O. in the matter of social security. But even he will have to admit that the Convention No. 102 is in urgent need of revision. But that appears to be very difficult to achieve.

4. A NEW CONCEPTION : THE SOCIAL SECURITY PROGRAM OF THE WORLD BANK

When one tours around in the world as a so-called "expert" on social security, as I have done now and then, one notices a practically total absence of reference to the I.L.O. standards in developing countries. The I.L.O. instruments have been completely eclipsed by a new conception of "social protection" - as the new terminology goes spread throughout the world by the World Bank. The World Bank is not mandated to deal with social security, or "social protection" as it prefers to call it. It is meant to finance programs in developing countries, helping these countries on the way to economic development. In doing so, it has, of course, to consider the conditions under which it provides loans to these countries, conditions which comprise improvements in the public finances of these countries. Social security programmes represent an important part of these public finances, and have very often to be reformed, in order to create favourable conditions for economic development.

The World Bank believes in an (moderately) neo-liberal economic theory, according to which the public sector expense is considered wasteful, and should be reduced to a minimum. Private business should be developed to the highest possible extent, and market mechanisms should be brought into play wherever possible. It is clear that they don't see the traditional social insurance schemes with an approving eye. On one side they want to scale them down to a "social safety net", meant to prevent or to fight poverty, and on the other side, they want to replace them by fully funded and privately managed pension funds "Chilean style", where the non poor can provide for their own future.

Such schemes appear to be much more modern than the old-fashioned social security systems. They are directed at industrial workers, who in the present-day workers are not identical with the poor, and who in underdeveloped countries may appear even as a relatively privileged group. They are directed at what is the real problem: that of serious poverty. They cost less to the government, which is particularly important for underdeveloped countries. Their financing system is oriented towards capital building, for investment in economic development. Their management system appears to be more market-oriented and efficient. And if all of these things were not sufficient to convince governments, adopting such schemes is a condition for obtaining financing from the World Bank, which is often vital for these countries.

The head of the World Bank's social protection department, Robert Holzmann, will be here to discuss his institutions policies in this field. So I will not dwell upon them more than to say that, contrary to the old-fashioned social security systems, these modern schemes have not proved themselves in reality. Where they were instituted they have not abolished poverty, they have not given workers with pensions and they have not helped economic development. The classic social security systems seem to have done much better on these counts. But let us not anticipate on the discussion. 


\section{TIME FOR AN INTERNATIONAL SCHEME?}

It is clear that what the authors of article 23 of the Universal Declaration of Human Rights, and of the International Covenant on Economic, Social and Cultural Rights had in mind, has failed. We are now well into the $21^{\text {st }}$ century, and it is estimated that only some $20 \%$ of the worlds population enjoy social security in a real sense, some $30 \%$ more have some sort of social security cover, but about $50 \%$ of the world population has no social security of any kind. So, in the sense of article 23, half of the world's population are not considered to belong to human society. This is clearly an intolerable situation.

The United Nations, the ILO, the World Bank and innumerable other official or non governmental organisations have undertaken all kinds of actions to combat poverty and bring some social protection to underprivileged populations around the world. They have financed projects, given grants in aid, provided material aid, given technical assistance, advice and training. Valuable as their efforts may have been, they have failed. Extreme poverty may have been reduced to some extent, but it has certainly been far from eradicated, and the gap in standard of living between the rich and the poor in the world is constantly widening.

It seems to me that the time has come to take a different approach.

Social security has traditionally been associated with the national state. It has originated in industrialisation, at the time when the national state was at the peak of its importance. The State is by itself an instrument of protection. It is meant to provide people with that vital protection, which they are unable to secure for themselves. When at the time of the industrial revolution, economic development had reached a sufficient level for States to become capable of providing protection against loss of income, social protection soon became an inherent responsibility of States.

At the present time, States are losing some of their absolute sovereignty. They lose it in both directions, outside their borders, and inside. Regions within States gain more autonomy, notably in the area of social protection (essentially health care and social assistance), And international organisations in various fields are gaining ground in obtaining real powers over national States, where the interests of the international community are supposed to be at risk. One should not only think of the Security Council of the United Nations, but also of the World Trade Organisation and, closer to home, of the Court of Human Rights of the Council of Europe, and of certain social Directives and Regulations of the European Union. If one wants to take the right to social, as a right of every member of human society, at all seriously, then the international community should take some tangible steps to enforce this right.

The very notion of solidarity, on which our social security systems are based, demands a universalisation of its extent. It is contrary to the idea of solidarity itself, to limit it to a certain group to which one belongs. Solidarity within one one occupational group, or within one nation, is limited solidarity. It means absence of solidarity with the others, who may need it more. When this limited solidarity occurs among the rich, to the exclusion of the poor, it is not solidarity at all. It is protectionism and collective selfishness, that does not deserve the name "social". 
In fact, enormous amounts are already spent on aid and assistance to the poorest countries, much in the same way that public assistance and private charity were distributed to the poor in the centuries before the coming of social insurance and social security. These efforts show that there is a will to do something for the underprivileged. One has to respect the good intentions shown and to appreciate the results obtained. But one also has to remember why charity and assistance were considered not enough, and why they gave way to modern social security: charity and assistance is not a right. They are essentially unreliable, since they depend on discretionary decisions by the donors, and, worse still, on awareness of problems in public opinion. They are unequally distributed, both at the giving and at the receiving end. And most important of all: they are offensive to human dignity. One should not receive as a gift, what one is entitled to as a right.

It is clearly in the interest of the rich themselves, both within the underdeveloped nations and in the industrialised world, to eradicate poverty and to promote a decent standard of living among the poor. It does nobody any good to be rich and surrounded by poverty. Not only are the poor a threat for peace and stability. They are also necessary to the high productivity countries as markets for their products, which they can buy only of their standard of living is high enough. And one should mention also the problem of illegal immigration in the rich countries, which causes social unrest. If all people in the less developed countries would be assured of a decent level of social protection at home, there would be much less of an incentive for young people in these countries to try to escape towards the rich countries. All of this should be reason enough to organise some basic form of social security for all those who are now deprived of it.

The mechanisms for putting such a scheme into place do exist. All countries in the world, nowadays, possess social security systems of some sort. The International Social Security Association (I.S.S.A.) counts almost as many members as the U.N. It is true that these systems very often cater only for a relatively small, and sometimes for a very small minority of their population. The majority of workers in what is called the informal economy simply don't have the capacity to pay contributions to a social insurance scheme. But minimum benefits could be paid to all the elderly, all invalids, and all children, and a basic medical care system could be financed, if the growing rich group in these countries paid a solidarity contribution, and if an adequate transfer were made from the industrialised nations.

Such transfer payments could, for instance, be managed by the World Bank, which would have the authority to make countries depending on its funding participate in the scheme.

To make it compulsory, and to monitor the adequate level of financing and of benefits, one could use the World Trade Organisation. In reality, a number of underdeveloped countries already have a social security scheme for the private sector because of the requirements of international trade. They must have this in order to avoid accusations of social dumping, and to be granted "most favorite nation" status by the U.S. or preferential import tax rates by the European Union. It would be a logical step to make participation in a minimum social protection scheme compulsory 
for all countries wanting to be members of the W.T.O. In the present-day world one may rightly consider that countries not paying their fair share in the cost of basic social protection are guilty of social dumping and of unfair competition. They should not be allowed to reap the profits of globalisation, if they are not willing to pay their penny to those who can not compete in it.

Would all of this be terribly expensive? Of course, providing basic benefits to half the world's population can not be done on a small budget. But as long as the standard of living in these countries is so low as it is to-day, the benefits needed to provide for basic income social protection for these people will be very small, compared to social protection budgets in industrialised nations. And when the standard of living in the underdeveloped countries starts to rise, the need for transfers from the rich nations will diminish.

And let us make another comparison: one should take a look at the incredible amounts spent on warfare, on arms and ammunition in the world to-day. I have not made the count, but I am certain that it would be many times the amount needed for basic social protection. All the weapons in the world can not produce peace. But some measure of social protection can do a lot to reduce social injustice, which is at the basis of a lot of conflicts in the world. As the preamble of the constitution of the I.L.O., the famous "Declaration of Philadelphia" said it: "universal and lasting peace can be established only if it is based upon social justice". That is ultimately what the right to social security is all about. 